\title{
Perspectives of Nigerian Youths on the Usage of Social Media and Their Academic Performance
}

\author{
OLANREWAJU, B.S. \\ Dept. of computer Science \\ Wellspring University \\ Benin City, Edo State, Nigeria
}

\author{
OLAYINKA, T.C. \\ Dept. of computer Science \\ Wellspring University \\ Benin City, Edo State, Nigeria
}

\begin{abstract}
Numerous efforts have been made to understand the impact and particularly the use of social media in education. However, how do the youths see the benefits of using social media for improved academic performance? This research is spurred by the aim to know if students think social media could be used to enhance their academic performance. The study assessed the use of social media among young students by exploring their views about the academic benefits that could be derived from its usage with the objectives of knowing if there is a link between social media usage and academic performance, which social medium platform has greater impact on the youths, which gender use social media the more and if it translate to good academic performance among the gender and thereby make recommendations on how to use social media to enhance their academic performance. This study is based on completed questionnaire survey of students and the method of data analysis adopted is chi square. The study is conducted in Benin City, Edo state, Nigeria. The result of this research shows that there is a link between social media and academic performance of youths. In the survey, $91 \%$ of the students use social media out of which $65.9 \%$ appreciate the impact of the social media on their academic achievements. The study also reveals that Facebook has the highest usage among the students. The research also concluded that the higher usage of social media by female does not translate to higher academic achievement. This makes gender usage of social media insignificant in academic achievement of youth. One of the recommendations of this study is that Students should be encouraged to create study groups or forum on social media to facilitate the exchange of information relating to their class work.
\end{abstract}

Keywords: social media; education; Nigerian youths; students; academic performance.

\section{INTRODUCTION}

Social media which includes social networking sites and blogs where people can easily connect with each other plays a vital role in transforming people's life style [1]. Fundamentally, social networks sites are a category of community sites that have profiles, friends, and comments [2]. For youth, using social media sites can help promote creativity, interaction, learning and solution to assignments and class works and also to interact with other classmates [3]. Social media Web sites usage is among the most common activity of today's youth [4]. Any Web site that allows social interaction is considered a social media site. Examples include Facebook, MySpace, 2go, Twitter, etc.

Youth are among the most prolific users of social media. Studies have shown that youth spend a considerable portion of their daily life interacting through social media. Academic activities can also benefit from the opportunities provided by social networking sites (SNSs) for secondary and higher education. Despite the fact that there are potential benefits or harmful effects of using SNSs, educators are seeking a new and innovative way to try to engage students and improve student achievement. Numerous efforts have been made particularly to understand the use of social media in education and how it can elevate the quality of learning in higher learning institutions.

The primary goals of this study were to describe why and how students use social media. The study aims to assess the use of social media among young students with the objectives of exploring the views of young students about the purpose and academic benefits that could be derived from its usage. Another objective of the study is to make recommendations on how social media could be put into positive use to improve the academic lives of youth.

More specifically, the study sought to do the following:

i. Identify social networking sites that could foster the improvement of educational practices and student learning.

ii. Clarify how social networking sites directly and indirectly influence the academic lives of youths.

iii. Describe the ways in which social networking sites help youths to acquire the will and skill required to improve student learning.

Based on the purpose of this study, the following hypotheses were made:

H1. Social media is not significantly affecting educational achievements of students.

H2. Facebook social medium affect students achievements than any other media.

H3. Gender effect is not significantly strong in discussing effects of social media on academic achievements of students.

Social media use has increased in recent years across all age levels. Social media has also been implemented in academic settings to motivate students to participate, share, and learn with other collaborators. The fact that social media is now very popular among youth makes it a vital method of improving the academic lives of youth, thus the importance of the study.

\section{LITERATURE REVIEW}

The prevalence of social media in the lives of young people has brought interest and concern about its impact on their education, skill development and learning in general.

One of the many questions concerning social media is that what kinds of effects these technologies have on youth development. 
Social media is the social interaction among people in which they create, share or exchange information and ideas in virtual communities and networks and it depends on mobile and webbased technologies to create highly interactive platforms through which individuals and communities share, co-create, discuss, and modify user-generated content [5].

Social media technologies take on many different forms including magazines, Internet forums, weblogs, social blogs, micro blogging, wikis, social networks, podcasts, photographs or pictures, video, rating and social bookmarking. The article by [6] defines social media as a group of new online media which have most or all of the following characteristics:

i. Participation: Social media promotes contribution and feedback from users who are interested in participating; therefore it blurs the line between media and the audience.

ii. Openness: Social media is accessible to people, it does not have any sort of barriers that prohibit access to users

iii. Conversation: Two-way communication is what makes social media stand out from the traditional media

iv. Community: Social media provides people with a platform to share common interests which promote sense of community amongst the users

v. Connectedness: Links to various sites, people, networks etc promote social media's ability to connect it's users to various areas of interest.

According to a study in America by [7], almost all sampled youth have used social media. Nine out of ten (90\%) 13- to 17year-olds have used some form of social media. Three out of four $(75 \%)$ teenagers currently have a profile on a social networking site, and one in five $(22 \%)$ has a current Twitter account (27\% have ever used Twitter). Facebook utterly dominates social networking use among teens: $68 \%$ of all teens say Facebook is their main social networking site, compared to $6 \%$ for Twitter, $1 \%$ for Google Plus, and $1 \%$ for MySpace (25\% don't have a social networking site).For the vast majority of teens, social and other digital communications media are a daily part of life. Two-thirds (68\%) of teens text every day, half $(51 \%)$ visit social networking sites daily, and $11 \%$ send or receive tweets at least once every day. In fact, more than a third (34\%) of teens visits their main social networking site several times a day. One in four (23\%) teens is a "heavy" social media user, meaning they use at least two different types of social media each and every day.

In his article, $A$ to $Z$ of social media for academia, [8] provides an overview of how to use social media in a way that enriches academic working life. However, the extent at which youth has used this technology for academic development is a question to be studied.

A research by [9] received much media attention with findings that college Facebook users have lower GPAs than students who are not users of the site. [9] offers several hypotheses for these findings. For example, perhaps Facebook users spend too much time online and less time studying. [10] note several clear limitations of the study in [9]. First, the sample of students is clearly limited. From this analysis, the researchers, find that Facebook usage has no significant relationship to GPA in any of their data sets. The researchers in this debate suggest that the Facebook-GPA relationship is an interesting avenue for future studies. However, aside from the fact that many youth use
Facebook, there appear to be no substantive theoretical reasons why Facebook use might influence GPA. As noted earlier, adolescents use the Internet for diverse communication and social goals. If perhaps a large percentage of youth interactions on Facebook were school or academic related, one might find a relationship to measures such as GPA. However, measurement of these communication patterns is lacking in the current literature and is a critical area for additional studies. The work of new media literacy researchers provides one avenue to better specify behaviors that might lead to learning. Most studies of social media and youth education define learning from a literacy perspective $[11,12]$.

Many schools have started to use these sites to promote education, keep students up to date with assignments, and offer help to those in need [2]. In general, the Internet and social networking sites can be a positive influence on adolescents. Social networking sites provide an outlet for teens to express themselves in their own unique ways [2]. In addition, they serve both as a meeting place for teens to interact with other likeminded people and as showplaces for a teen's artistic and musical abilities [2]. Finally, high school students use these sites as tools to obtain information and resources for graduation preparation and future planning. For example, students applying for college visit profiles of that college's students to view pictures and read blogs of past students to determine whether the college would be a good fit [2].

\section{METHODOLOGY}

This study is based on completed questionnaire survey of students in Edo state Nigeria. The survey included a series of questions to determine the impact of social media on academic lives of youths

This consists of secondary and those in the tertiary institutions which include both genders and those from different ethnic and religious backgrounds. The average age of these students is twenty-one years.

Simple random sampling method, targeting youths in secondary and higher institutions was adopted for this study. Visits were made to different identified accessible categories of schools where questionnaires were distributed at random. Systematic sampling was also used to capture the views of students of different classes or levels in these schools abut social media. The samples are as follows:

i. Secondary Schools: Senior Secondary School 1 (SSS 1), Senior Secondary School 2 (SSS 2) and Senior Secondary School 3 (SSS 3)

ii. College of Education: Part 1, Part 2, and Part 3

iii. University: 100, 200, 300, 400, and 500 levels

The study is based on questionnaire survey. Questionnaires containing both open and close ended questions were distributed among the students. The questionnaire has questions on activities on social media and demographic questions including age, gender, average grade in school, location of residence, if and how long the participant has been using any social media site. The questionnaire aims to assess how, if at all participants use social media for academic purposes and to what degree is the effect of the general usage of the site on the academic performance of participants.

It is ensured that the questions fully represent the domain of the effects of social media on academic lives of youth. The reliability of the questionnaire is ensured through carefully manipulated repeated highly correlated questions of the questionnaire. The questions are structured to measure the impact of social media on academic lives of youth. Questionnaires were delivered to the respondent by direct visitation for interactive completion. The administration of the 
research instrument occurs at the same time or following some time delay among the respondents. The participants were carefully selected to capture the domain of interest that is, youth. The questionnaire was made to be interesting, of value, short, clearly thought through and well presented to obtain a higher likelihood of respondents answering the questionnaire. The method of data analysis that is adopted is chi square.

\section{RESULTS AND DISCUSSION}

\subsection{Results}

Hypothesis I: Social media is not significantly affecting educational achievements of students.

The null hypothesis $\left(\mathrm{H}_{0}\right)$, states that there is no association between social media and academic achievement of youth. The alternate hypothesis $\left(\mathrm{H}_{1}\right)$ states that social media have association with academic achievement of youth. The hypothesis is tested considering students that use social media for educational purpose and those that do not use it for this purpose. Also, those that do not use it at all are also considered. The total number of students that use social media for educational purposes $(A)=64$

The total number of students that use social media but not for educational purposes $(B)=27$

The total number of students that do not use social media $(\mathrm{C})=$ 9

Based on this classification the hypothesis is tested by asking these three categories if they have noticed the effect of the use of social media or they believe that social media has the capacity to improve their academic achievement.

The observed versus expected counts is shown in table 1 below:

Table 1: Observed Versus Expected Counts of Social Media Affecting Academic Achievement of Students

\begin{tabular}{|c|c|c|c|c|}
\hline & YES & NO & $\begin{array}{c}\text { DON'T } \\
\text { KNOW }\end{array}$ & TOTAL \\
\hline $\mathrm{A}$ & $\begin{array}{c}45 \\
(39.68)\end{array}$ & $\begin{array}{c}10 \\
(10.88)\end{array}$ & $\begin{array}{c}9 \\
(13.44)\end{array}$ & 64 \\
\hline $\mathrm{B}$ & $\begin{array}{c}15 \\
(16.74)\end{array}$ & $\begin{array}{c}5 \\
(4.59)\end{array}$ & $\begin{array}{c}7 \\
(5.67)\end{array}$ & 27 \\
\hline $\mathrm{C}$ & 2 & 2 & 5 & 9 \\
& $(5.58)$ & $(1.53)$ & $(1.89)$ & \\
\hline TOTAL & 62 & 17 & 21 & 100 \\
\hline
\end{tabular}

Using the Chi-square formula, the Chi-square value was calculated for each of the cell.

$$
\begin{aligned}
& X_{A 1}^{2}=0.713 \quad X_{A 2}^{2}=0.071 \\
& X_{B 1}^{2}=0.181 \quad X_{B 2}^{2}=0.037 \\
& X_{C 1}^{2}=2.297 \quad X_{C 2}^{2}=0.144 \\
& 0.181+0.037+0.312+2.297+0.144+5.117 \\
& =10.34
\end{aligned}
$$

The degree of freedom $(\mathrm{df})=($ number of row -1$) \times($ number of column -1) $=(3-1) X(3-1)=4$

From the chi square distribution table, the probability value (pvalue) for the calculated $X^{2}$ and df is less than 0.05 which is the level of significance. This result implies that there is negligible probability ( $p<0.05$, i.e. less than $5 \%$ ) that the observed value occurred by chance. It is therefore concluded that association exists between social media and academic achievement of youth. The null hypothesis is therefore rejected.

Hypothesis II: Facebook social medium affects students' achievements than any other media.
The null hypothesis $\left(\mathrm{H}_{0}\right)$, states that Facebook social medium does not affect students achievements more than any other media. The alternate hypothesis $\left(\mathrm{H}_{1}\right)$ states that Facebook social medium affects students' achievements more than any other media. The hypothesis is tested considering only students that use social media.

The total number of students that use Facebook more than other social media $(\mathrm{A})=58$

The total number of students that use other social media more than Facebook $(B)=33$

Based on this classification, the hypothesis is tested by asking these two categories of students whether social media affect their academic achievement. The table 2 below shows the observed versus expected counts:

Table 2: Observed Versus Expected Counts of Numbers of Students Using Different Types of Social Media

\begin{tabular}{|c|c|c|c|c|}
\hline & YES & NO & $\begin{array}{c}\text { DON'T } \\
\text { KNOW }\end{array}$ & TOTAL \\
\hline $\begin{array}{c}\text { FACEBOOK } \\
\text { (A) }\end{array}$ & 47 & 4 & 7 & 58 \\
$(38.242$ & $(9.560$ & $(10.198)$ & \\
\hline $\begin{array}{c}\text { OTHERS } \\
\text { (B) }\end{array}$ & 13 & 11 & 9 & 33 \\
$(21.758$ & $(5.44)$ & $(5.802)$ & \\
\hline TOTAL & 60 & 15 & 16 & 91 \\
\hline
\end{tabular}

Using the Chi-square formula, the Chi-square value was calculated for each of the cell.

$$
\begin{array}{llr}
X_{A 1}^{2}=2.006 & X_{A 2}^{2}=3.234 & X_{A 3}^{2}=1.003 \\
X_{B 1}^{2}=3.525 & X_{B 2}^{2}=5.680 & X_{B 3}^{2}=1.763 \\
X^{2}=2.006+3.234+1.003+3.525+5.680+1.763 \\
\quad=17.21 & \\
\text { df }=(2-1) X(3-1)=1 \text { X } 2=2 &
\end{array}
$$

The $\mathrm{p}$-value for the calculated $\mathrm{X}^{2}$ and df of 2 is less than 0.05 (about 0.001) which is far below the level of significance. This result implies that there is negligible probability that the observed value occurred by chance. The null hypothesis is therefore rejected and concludes that Facebook social medium affects students' achievements more than any other media.

Hypothesis III: Gender effect is not significantly strong in discussing effects of social media on academic achievements of students. The null hypothesis $\left(\mathrm{H}_{0}\right)$, states that gender has nothing to do with the effect of social media on academic achievements of students. The alternate hypothesis $\left(\mathrm{H}_{1}\right)$ states gender determines the extent to which social media affect academic achievements of students. The hypothesis is tested by considering the number of male and female students that use social media and think that there is a measure of effects in the usage of social media on academic achievements of students. The table 3 below shows the observed versus expected counts:

Table 3: Observed Versus Expected Counts of Gender Agreeing that Social Media Affect Academic Achievement of Students

\begin{tabular}{|c|c|c|c|}
\hline & YES & NO & TOTAL \\
\hline $\begin{array}{c}\text { Male } \\
(\mathrm{A})\end{array}$ & 36 & 18 & 54 \\
\hline $\begin{array}{c}\text { Female } \\
(\mathrm{B})\end{array}$ & $192.637)$ & $(21.363)$ & \\
\hline TOTAL & $52.363)$ & $(14.637)$ & 37 \\
\hline
\end{tabular}


Using the Chi-square formula, the Chi-square value was calculated for each of the cell.

$$
\begin{aligned}
& X_{A 1}^{2}=0.347 \quad X_{A 2}^{2}=0.529 \\
& X_{B 1}^{2}=0.506 \quad X_{B 2}^{2}=0.773 \\
& X^{2}=0.347+0.529+0.506+0.773=2.155 \\
& \text { df }=(2-1) X(2-1)=1
\end{aligned}
$$

For the values of $\mathrm{X}^{2}$ and $\mathrm{df}$, The p-value is more than 0.05 (about 0.1 ) which is above the level of significance. The null hypothesis is therefore accepted and concludes that gender does not determine the extent to which social media affect academic achievements of students.

\subsection{Discussion}

This study investigated the link between social media and academic achievement of youths under three hypotheses.

\section{Hypothesis I}

The result of this research shows that there is a link between social media and academic achievements of youths. In the survey as shown in Table 4.1, 91\% of the students use social media out of which $65.9 \%$ appreciate the impact of the social media on their academic achievements. This is in agreement with the findings of [13] that students who participate in course work that utilize social media demonstrate an increase in overall GPA when compared with students who do not participate in social media.

\section{Hypothesis II}

The study also reveals that Facebook has the highest usage among the students. The number of students using different types of social media sites is given in the table 4 below:

Table 4: How Students Use different Types of Social Media

\begin{tabular}{|l|c|}
\hline Social Media & $\begin{array}{c}\text { Number of students } \\
\text { (Out of 100) }\end{array}$ \\
\hline Facebook & 83 \\
\hline Whatsapp & 56 \\
\hline Twitter & 46 \\
\hline 2go & 37 \\
\hline Instagram & 24 \\
\hline BBM & 18 \\
\hline Badoo & 12 \\
\hline Others & 9 \\
\hline
\end{tabular}

Considering this frequency of usage, Facebook is believed to have the greatest impact on the academic achievement of students because of its high usage.

\section{Hypothesis III}

Although, some studies in USA like [14] claims that more women are getting online than men and this trend is expected to increase in the next few years, this study however, shows that gender is not related to how social media influence the academic achievements of students. Females may be using social media more than males but this does not suggest that they are using it more on academics which could have made the impact more on their academic than that of males. As a matter of facts as shown in table 5, this survey found that $64 \%$ of the respondents support the idea that female use social media more than male, $9 \%$ think otherwise while $27 \%$ believe social media are used equally. However, out of the 42 females that participated in the survey (Table 6), 14 (about 33.3\%) believe that social media affects academic achievement, 12 (about $28.6 \%$ ) think otherwise while 16 (about $38.1 \%$ ) don't know the effect. It then means that only one-third of the female could

www.ijcat.com show the effect of social media on their academic performance. Therefore, it could be concluded that the higher usage of social media by female does not translate to higher academic achievement. This makes gender usage of social media insignificant in academic achievement of youth.

Table 5: Gender Usage of social Media

\begin{tabular}{|c|c|c|}
\hline $\begin{array}{c}\text { Male Usage more } \\
\text { than Female } \\
\text { Usage }\end{array}$ & $\begin{array}{c}\text { Female Usage } \\
\text { more than Male } \\
\text { Usage }\end{array}$ & $\begin{array}{c}\text { Usage The } \\
\text { Same }\end{array}$ \\
\hline $64 \%$ & $27 \%$ & $9 \%$ \\
\hline
\end{tabular}

Table 6: Effects of Social Media on Academic achievements of Females (42 Female Respondents)

\begin{tabular}{|c|c|c|}
\hline YES & NO & DON'T KNOW \\
\hline 14 & 12 & 16 \\
\hline
\end{tabular}

\section{SUMMARY, CONCLUSION AND RECOMMENDATIONS}

This study was carried out to investigate the effects of social media on academic achievement of youths. One hundred questionnaires containing both open and close ended questions were administered among students of secondary and tertiary institutions. In line with the aims of this research, three hypotheses were formulated. The first test confirmed that the use of social media can affect the academic achievement of youth. Secondly, the study showed that Facebook social medium affects student achievements than any other media. Thirdly, the study revealed that gender has nothing to do with how social media affect youth's academic achievements.

The study presents a general trend of social media usage among students. It was found that Facebook is the most used social media sites follow by Whatsapp, Twitter, 2go, Instagram, BBM, Badoo and others in that order. Based on the results of this research, it is therefore concluded that social media has the capacity to help improve the academic achievement of youths. This is however possible when youths use these media for academic purposes. Facebook social media is mostly used and if tutors or lecturers can use this medium to teach, it will enhance the performance of students.

This study investigated how much social media affects academic performance of youths. The key findings of this study have further strengthened the literatures such as [15] that confirm the link between academic performance of students and social media.

Another result of this study reported the dominance of Facebook usage among students and this will lead to further research on why students tend to use Facebook the more.

The study affirmed the insignificance of gender in the usage of social media and academic performance.

The following recommendations are made on the basis of findings of the study:

1. The students at various levels should be provided with better Internet connections to promote the use of social media among young students.

2. The use of social media should be integrated with the conventional class room teaching and learning process. 
3. The teachers should enhance their skills in the use of these media, so they could be able to cope with these emerging global trends.

4. Teachers should encourage the use of social media for educational purposes by posting assignments, questions and tutorials on the media, knowing that a large proportion of students use the media.

5. Students should be encouraged to create study groups or forum on social media to facilitate the exchange of information relating to their class work.

\section{REFERENCES}

[1]. Shabnoor. S. and Tajinder, S. (2015). Social Media its Impact with Positive and Negative Aspects. International Journal of Computer Applications Technology and Research, Volume 5- Issue 2, 71 - 75, 2016, ISSN:- 23198656.

http://www.ijcat.com/archives/volume5/issue2/ijcatr0502 1006.pdf

[2]. Boyd, danah. (2007) "Why Youth (Heart) Social Network Sites: The Role of Networked Publics in Teenage Social Life." MacArthur Foundation Series on Digital Learning - Youth, Identity, and Digital Media Volume (ed. David Buckingham). Cambridge, MA: MIT Press.

[3]. Ahn (2011). The Effect of Social Network Sites on Adolescents' Social and Academic Development: Current Theories and Controversies

[4]. Papaioannou, 2011. Assessing Digital Media Literacy among Youth through Their Use of Social Networking Sites

[5]. Chiemela Q.A., Ovute A.O and Obochi C.I. (2015). The influence of the social media on the Nigerian youths: Aba residents experience. Journal of Research in Humanities and Social Science, Volume $3 \sim$ Issue 3 (2015) pp:12-20 ISSN(Online $)$ : 2321-9467

[6]. Antony Mayfield (2008). What is Social Media? Available online http://www.icrossing.com/uk/sites/default/files_uk/insight _pdf_files/What\%20is\%20Social\%20Media_iCrossing_eb ook.pdf
[7]. Common Sense Media (2012). Social Life: How Teens View Their Digital Lives. A Common Sense Media Research Study. Summer 2012.

[8]. Andy Miah (2014). The A to Z of Social Media for Academia

[9]. Karpinski, A. C. (2009). A description of Facebook use and academic performance among undergraduate and graduate students. Paper presented at the Annual Meeting of the American Educational Research Association, San Diego, CA.

[10].Pasek, J., More, E., \& Hargittai, E. (2009). Facebook and academic performance: Reconciling a media sensation with data. First Monday, 14 (5), http://firstmonday.org/htbin/cgiwrap/bin/ojs/index.php/f $\mathrm{m} /$ article/view/2498/218.

[11].Ito, M., Baumer ,S., Bittanti, M.,boyd, d., Cody, R.,\& Herr-Stephenson, B. (2009). Hanging out, messing around, and geeking out: Kids living and learning with new media. Cambridge, MA:MIT Press.

[12].Jenkins, H. (2006). Confronting the challenges of participatory culture: Media education for the $21^{\text {st }}$ century. Chicago: The John D.and Catherine T. MacArthur Foundation.

[13].Junco, R., Helbergert, G., \& Loken, E. (2011). The effect of Twitter on college student engagement and grades. Journal of Computer Assisted Learning, 27, 119-132. doi:10.1111/j.1365-2729.2010.00387.x

[14].Tech Crunchies. (2008). Internet statistics and numbers. Retrieved February 1, 2011, from http://techcrunchies.com/males-vs-females-internetusers-in-usa/

[15].Carini, R. M., Kuh, G. D., \& Klein, S. P. (2006). Student engagement and student learning: Testing the linkages. Research in Higher Education, 47(1), 1-32. doi: 10.1007/s11162-005-8150-9 